Revised and resubmitted: October 23, 2003

\title{
A Critical Look at the Use of Group Projects as a Pedagogical Tool
}

This article was published in the Journal of Education for Business, vol. 79, no. 4 (2004)

\author{
Mohammad Ashraf \\ Assistant Professor of Economics \\ School of Business \\ The University of North Carolina at Pembroke \\ P.O. Box 1510 \\ Pembroke, NC 28372-1510 \\ Phone: (910) 521-6464 \\ Fax: (910) 521-6564 \\ Email: mohammad.ashraf@uncp.edu \\ Web: www.uncp.edu/home/ashraf
}


A Critical Look at the Use of Group Projects as a Pedagogical Tool

\begin{abstract}
An Abstract
In business schools across the U.S. one of the most common pedagogical tools is the use of groups and group projects. "Passive" instruction, i.e., lecture only, is considered to be an inferior mode of teaching. It is suggested in this paper that the use of group-based projects as pedagogical tools should be reconsidered. Because of the difference in the "number" of games played in a real work environment versus in the classroom setting, and the knowledge thereof, the problem of free riding in a classroom setting intensifies. Relatively less motivated students end up getting higher grades at the cost of lower grades for industrious students.
\end{abstract}

JEL code: A20; A22; A23 
In business schools across the U.S., the use of groups and group projects is very common. "Passive" instruction, i.e., lecture only, is considered to be an inferior mode of teaching (Bartlett 1995a, 1995b; Batra, Walvoord, \& Krishnan, 1997; Bowen, Kent, Clark, Holloway, \& Wheelwright, 1994; Comer, 1995; Goodsell, Maher, \& Tinto, 1992; Johnson, Johnson, \& Smith, 1991; Kerr, 1983; McCorkle, Diriker, \& Alexander, 1992; McKinney \& Graham-Buxton, 1993; Moore, 1998; Rau \& Heyl, 1990; Strong \& Anderson, 1990; William, Beard, \& Rymer, 1991). Economics courses, however, seem to be the exception where professors prefer lecture and chalk board techniques (Benzing \& Christ, 1997; Becker \& Watts, 2001).

As the substantial benefits of teamwork to the firm became known, employers expected and received an increased emphasis on group-based class projects by the schools. In a recent study, Hamilton, Nickerson and Owan (2003) found that on average, with the introduction of teams, productivity at a garment plant increased by 14 percent. Educators try to instill the value of teamwork in students by using group-based class projects. The question addressed here is whether a classroom setting is conducive to learning how to be a team player. A game theoretic approach is utilized to support the argument that a classroom setting is different from the real world.

A major difference between classroom and workplace is that in a classroom, students play a finite number of games with the number of games known. In a work environment, however, workers play a finite number of games with the number of games unknown. As such, a classroom setting is not necessarily conducive to learning how to be a team player. 
There are six different group situations presented in this paper. These scenarios demonstrate that "Less Motivated” students get better grades at the cost of lower grades for "Industrious" students.

Various teaching and learning benefits of group projects have been discussed in the business pedagogical literature. Some of the benefits that supposedly accrue to students listed in literature include cooperative and peer learning, peer modeling, teamwork, and efficiency. The benefits that presumably accrue to professors, mentioned in literature, include fewer papers to grade and the freedom to assign more comprehensive projects.

The literature on the topic also criticizes the practice of assigning group projects in a classroom setting because of the possibility of free riding; high transaction costs, especially if students are commuting from different places or have inflexible schedules due to other obligations (e.g. family, work); poor product quality; stifled individual creativity because of within group dynamics; and poorly structured job, which may result in delays.

It is also argued that group projects serve as latent barriers to learning new skills. Students tend to divide the workload of a large project, and a given student will pick the task that he/she has done in some other project. This means that the student will not learn any new skills. This will also lead to the absence of broader knowledge.

From this brief review of the existing literature on the topic, there is not enough evidence for or against the use of groups and group projects as pedagogical tools. Furthermore, the existing literature is primarily anecdotal. It is based on personal opinion. Studies rely on survey data, and lack rigor in collection and the analyses of data. These 
concerns warrant interrogation of the use of groups and group projects as pedagogical tools from a theoretical point of view.

The debate is not over the importance of teamwork. It is an established fact that employers seek a team player when making hiring decisions. The question is whether a classroom setting is appropriate for acquiring such skills. Does the use of groups and group projects as pedagogical tools pay off or does it train “Less Motivated” students to become proficient free riders at the cost of lower grades for "Industrious” students?

\section{Theoretical Models}

This section presents six models. The basic assumptions of these models are:

i. There are two major types of students: “Industrious" and "Less Motivated.” The titles of "Industrious" and "Less Motivated” are purely based on the GPA of the students and their aptitude toward work. That is, a student is considered "Industrious" if he/she has a high GPA and wants to work. On the other hand a student is considered "Less Motivated” if he/she does not want to work or has a low GPA, or both. The choice between working and not working depends upon the stakes. The higher the stakes a student has, the harder the student will work. An underlying assumption is that Industrious student always has higher stake compared with Less Motivated student. As such, Industrious student always works at least as hard as Less Motivated student.

ii. The models assume that there are benefits and costs associated with getting good grades. The benefits of good grades are obvious (e.g. better job opportunities, happier parents, self satisfaction, etc). However costs can be divided into two categories: One, costs associated purely with work required for the projects, $w$. These costs include the 
time spent on doing the research for the project, learning new techniques for analysis and putting the project together. Two, costs associated with pulling the weight of other student(s), $c$. These costs include trying to arrange meetings with the rest of the group members, time spent persuading other group members to move in a certain direction and explaining concepts to the rest of the group members. Formally speaking, let $P_{i}$ be the net payoff to student $i, b_{i}$ be the benefit from a good grade to student $i, w_{i}$ is the amount of work put in by student $i$, and $c_{i}$ is the cost associated with pulling the weight of the other student (for $i=$ Industrious, Less Motivated). The net payoff to student $i$ may be written as $P_{i}=b_{i}-w_{i}-c_{i}$. Since $w_{\text {Industrious }} \geq w_{\text {Less Motivated }}, c_{\text {Industrious }}>0$, and $c_{\text {Less }}$ Motivated $=0$, this implies that $P_{\text {Less Motivated }}>P_{\text {Industrious. }}$ That is, Less Motivated student's net payoffs are always greater than Industrious student's net payoffs and Industrious student bears the cost.

iii. Grades are awarded at the end of the project, and are based on the finished project and not on effort. The grading scale is: A, B, C and F (except in the cases of Models 5 and 6, where the choices are A and F). Where A is the highest and F is the lowest. Furthermore, $\mathrm{A} \succ \mathrm{B} \succ \mathrm{C} \succ \mathrm{F}$ for both Industrious and Less Motivated student.

iv. Groups may be formed in three ways: (a) Industrious student with Industrious student, (b) Less Motivated student with Less Motivated student, and (c) Industrious student with Less Motivated student. Furthermore, partners may be assigned by the professors. The assignment may be random or deliberate. Alternatively, students may pick their own partners.

These four assumptions are true for all models presented in this paper. However, each model has its own set of additional assumptions. 
Instructional Model 1 presented here assumes: (a) only one project; (b) two players, Industrious student and Less Motivated student; (c) perfect and complete information; and (d) no monitoring. That is, the professor does not know which student did how much work. As a result there are no penalties for shirking and both students get the same grade.

The payoffs matrix for Model 1 is presented in Table 1 . In the payoffs matrix, the first letter is the payoff of the row player and the second letter is the payoff of the column player, i.e., Less Motivated student and Industrious student, respectively. The matrix presents four possible situations: (a) neither Industrious student nor Less Motivated student work (grades are F, F); (b) Less Motivated student works but Industrious student doesn’t work (grades are B, B); (c) Industrious student works but Less Motivated student doesn’t work, (grades are B, B); and (d) both students work (grades are A, A).

Since by assumption Industrious student always works and Less Motivated student does not, this rules out situations (a), (b) and (d). The only possible outcome is presented by situation (c), where Industrious student works and Less Motivated student does not. Both students get B's. Note that situation (d) carries a payoff of grade A for both the students. This is because if both students work and neither has to carry the other's weight, the quality of work increases. However since Less Motivated student is a free rider and Industrious student has to carry the weight of the former, the overall grade suffers. That is, both students get B's.

Note also that the grade of Industrious student may decrease from A to B for two reasons: One, Industrious student has to carry the weight of Less Motivated student. This demands extra effort on the part of Industrious student. The effort expended on pulling 
Less Motivated student along could be directed towards the project, leading to a higher grade. Two, the grade is assigned to the finished project, and since the professor has no way of monitoring, there are no rewards for extra effort or penalties for shirking.

Instructional Model 2 carries the first three assumptions of Model 1. The fourth assumption of no monitoring is replaced with monitoring and it is assumed that shirking is penalized by lowering the grade of the shirker.

The payoffs matrix is presented in Table 2. Again, the only feasible outcome is presented in the upper-right corner. However, notice that Industrious student still suffers in terms of grade. He/she could have earned an A instead of a B if he/she did not have to pull Less Motivated student along. In other words, just penalizing Less Motivated student is not enough. Unless there is some reward for Industrious student in carrying Less Motivated student along, Industrious student will be short-changed in terms of grades.

Instructional Model 3 (payoffs matrix not presented) permits the students to pick their own partners. Along with the assumptions of one project and two students, Industrious student and Less Motivated, it also assumes perfect but (two-sided) incomplete information. That is, each player knows other player's actions before he/she makes his/her own move. However, each player is not aware of the other player's payoffs.

However notice that under the assumption that the amount of effort put in the project is a function of the level of stake (Assumption i), and each student knows what he/she has at stake for him/herself, the knowledge about the payoffs of other student becomes irrelevant. Industrious student always works and Less Motivated student always does not work. The presence of incomplete information and the ability to pick one's own 
partner do not change the results and Less Motivated student gets higher grades at the expense of lower grades for Industrious student.

Instructional Model 4 (payoffs matrix not presented) relaxes the assumption of having only one project but maintains the assumption of two students in a group, Industrious and Less Motivated. Players are expected to play finite repeated games with number of games known. It also assumes that each student has the chance to have the same partner in other class projects (or classes).

Would the knowledge that one could partner with the same student in later class projects change the way one student behaves in an earlier class projects? "Backward Induction” dictates that as long as the number of games is known, each player behaves as if it were a one-shot game. In our case the implication is that as long as the number of projects is known, the multiplicity of projects does not affect our outcome: Industrious student always works and Less Motivated student does not.

Instructional Model 5 (payoffs matrix presented in Table 3) relaxes the assumption of only two students in a group. It is assumed that there are three students in a group and at least two students are required to work to get a good grade. For the ease of exposition we maintain the assumptions of one project and no monitoring and further assume that: (a) grades are A and F, and (b) complete and imperfect information. That is, each student knows other students’ payoffs. However, each student does not know other students’ moves before he/she makes the move. As such, each student assigns a subjective probability $\theta$, $(0<\theta<1)$, to any other student's propensity to working.

The third student's decision to work or not plays the crucial role in the overall project grade. If the third student thinks, based on $\theta$, that the other two students will 
work, his/her preferred strategy would be not to work. On the other hand if the third student thinks, based on $\theta$, that only one other student will work, his/her decision to work or not to work will depend upon how badly he/she wants to avoid an F. That is, whether the student is Less Motivated student or Industrious student. If the third student is Industrious student and he/she thinks that only one other student will work, he/she will decide to work and the project grade will be an A (top-left corner). On the other hand if the third student is Less Motivated student, he/she will decide not to work, regardless of the decision(s) of other student(s).

Instructional Model 6 maintains the rest of the assumptions of Model 5 except that it has $N>3$ students in a group, and at least $k$ students have to work to get a good grade, where $N$ is the number of students and $k>N-k$.

The payoffs matrix is presented in Table 4 . In this model, the decision of the $i^{\text {th }}$ student to work or not to work plays the crucial role. If the $i^{\text {th }}$ student thinks, based on $\theta$, that $k$ other students will work, or that $k-2$ other students will not work, his/her preferred strategy would be not to work, regardless of whether the $i^{\text {th }}$ student is Industrious student or Less Motivated student. The project grades will be A (lower-right corner) and F (lower-left corner), respectively. In the event that $k$ - 1 other students work (middle column), the preferred strategy by the $i^{\text {th }}$ student depends upon his/her preferences for an A as opposed to an F. That is, whether the student is Industrious student or Less Motivated student.

Therefore, group projects allow students who do not work to take advantage of students who work, most often at the expense of lower grades for students who work. In infinitely repeated games or games with an unknown number of repetitions, the outcome 
may be different. In these cases backward induction does not apply. This affects the future strategies of players (students in our case) who do not work. The infinitely repeated games (or games with finite repetitions with unknown number of repetitions) scenario resembles the real workplace. However a classroom setting does not allow for infinitely repeated games. This makes the use of groups and group projects in a classroom setting not only ineffective, it often results in hurting the grades of students who work.

\section{Conclusion}

The ability to be a team player is one of the top characteristics that employers desire in a prospective employee. College and university professors across the U.S. try to introduce students with the benefits of teamwork by assigning group projects. Using a game-theoretic approach, groups and group projects in a classroom setting fail to achieve the expected results. Due to the nature of the classroom setting, the problem of free riding not only intensifies, it may result in making Less Motivated students proficient free riders. The models indicate that the use of groups and group projects as pedagogical tools should be reconsidered. The models also indicate that penalizing Less Motivated students for free riding is not enough. Unless there is some reward for Industrious students for carrying Less Motivated students along, Industrious student will be short-changed in terms of grades. That is, Less Motivated students will get good grades at the expense of lower grades for Industrious students. 


\section{References}

Bartlett, R. L. (1995a.). Attracting “otherwise bright students” to Economics 101. American Economic Review, 85(2), Papers and Proceedings of the Hundredth and Seventh Annual Meeting of the American Economic Association, 362-366.

Bartlett, R. L. (1995b). A flip of the coin--A roll of die--An answer to the free-rider problem in economic instruction. Journal of Economic Education, 26(2), 131139.

Batra, M. M., Walvoord, B. E. \& Krishnan, K. S. (1997). Effective pedagogy for studentteam projects. Journal of Marketing Education, 19, 26-42.

Becker, W. E. \& Watts, M. (2001). Teaching methods in U.S. undergraduate economics courses. Journal of Economic Education, 23(3), 269-279.

Benzing, C. \& Christ, P. (1997). A survey of teaching methods among economics faculty. Journal of Economic Education, 28(2), 182-188.

Bowen, H. K., Clark, K. B., Holloway, C. A. \& Wheelwright, S. C. (1994). Make project the school for leaders. Harvard Business Review, 72(5), 131-40.

Comer, D. R. (1995). A model of social loafing in real work groups. Human Relations, 48(6), 647-67.

Goodsell, A., Maher, M. \& Tinto, V. (Eds.). (1992). Collaborative learning: A source book for higher education. University Park, PA: National Center for Teaching, Learning, and Assessment.

Hamilton, B. H., Nickerson, J. A., \& Owan, H. (2003). Team incentives and worker heterogeneity: An empirical analysis of the introduction of teams on productivity and participation. Journal of Political Economy, 111(3), 465-497. 
Johnson, D. W., Johnson, R. T. \& Smith, K. A. (1991). Cooperative learning: Increased college faculty instructional productivity. ASHE-ERIC Higher Education Report No. 4. Washington, DC., The George Washington University, Scholl of Education and Human Development.

Kerr, N. L. (1983). Motivation losses in small groups: A social dilemma analysis. Journal of Personality and Social Psychology, 45(4), 819-28.

McCorkle, D. E., Diriker, M. F. \& Alexander, J. F. (1992). An involvement-oriented approach in a medium-sized marketing principles class. Journal of Education for Business. 67(4), 197-205.

McKinney, K. \& Graham-Buxton, M. (1993). The uses of collaborative learning group in the large class: Is it possible? Teaching Sociology, 21(4), 403-08.

Moore, R. L. (1998). Teaching introductory economics with a collaborative learning lab component. Journal of Economic Education. 29(4), 321-329.

Rau, W. \& Heyl, B. (1990). Humanizing the college classroom: Collaborative learning social organization among students. Teaching Sociology, 18(2), 141-55.

Strong, J. T., \& Anderson, R. E. (1990). Free-riding in group projects: Control mechanisms and preliminary data. Journal of Marketing Education, 12(2), 61-67.

Williams, D. L., Beard, J. D. \& Rymer, J. (1991). Team projects: Achieving their full potential. Journal of Marketing Education, 13(2), 45-53. 


\section{Table 1}

Instructional Model 1 Payoffs Matrix

\begin{tabular}{cccc} 
& \multicolumn{2}{c}{ Industrious Student } \\
& & Doesn't Work & Works \\
Less Motivated Student & Doesn't Work & F, F & B, B \\
& Works & B, B & A, A \\
\hline
\end{tabular}


Table 2

Instructional Model 2 Payoffs Matrix

\begin{tabular}{cccc} 
& & \multicolumn{2}{c}{ Industrious Student } \\
Less Motivated Student & Doesn't Work & Works \\
& Doesn't Work & F, F & C, B \\
& Works & B, C & A, A \\
\hline
\end{tabular}


Table 3

Instructional Model 5 Payoffs Matrix

$\begin{array}{ll}\underline{1 \text { Other }} & \underline{2 \text { Others }} \\ \text { Works } & \text { Work }\end{array}$

Works $\quad$ Project Grade: A Project Grade: A

$\underline{\text { Third Student }}$

Doesn’t Work $\quad$ Project Grade: F Project Grade: A 
Table 4

Instructional Model 6 Payoffs Matrix

$\begin{array}{ccc}\underline{k-2 \text { Others }} & \underline{k-1 \text { Others }} & \underline{k \text { Others }} \\ \text { Work } & \text { Work } & \text { Work }\end{array}$

Works Project Grade: F Project Grade: A Project Grade: A

$\underline{\text { Student } i}$

Doesn’t Work Project Grade: F Project Grade: F Project Grade: A 